\title{
Situating Mohammed Arkoun: A Tribute to a Passionate Critic
}

Abdallah Zbir

University of Ibn Tofail, Kenitra, Morocco

Corresponding Author: Abdallah Zbir, E-mail: Abdallahzbir02.az@gmail.com

\section{ARTICLE INFORMATION}

Received: November 17, 2020

Accepted: January 14, 2021

Volume: 4

Issue: 1

DOI: $10.32996 / i j l t .2021 .4 .1 .11$

\section{KEYWORDS}

Islam, critique, intellectual

struggle, reflection

\section{ABSTRACT}

The image of Arkoun as a brilliant scholar is highly recognized among his contemporaries. His philosophy is still being treated as a true work of mind, a reflection on reality and a representation of it whatever aspect it takes. Although it seems in adherence to consensus principles of thought and knowledge in the present time, it is very autonomous in the sense it deals with its subject-matters in decidedly Islamic terms; i.e., it belongs to Arkoun's own culture, tradition and history in many ways as far as it represents his own revolutionary state of mind, somehow, not a replicate of others'. In this context, it adds very significantly to the accumulation of modern thought in an Islamic intellectual atmosphere of despair and deception.

\section{Introduction}

Arkoun was well versed in Islamic tradition and modern social and humanistic sciences -most significantly for the purpose of his 'Applied Islamology', semiotics, anthropology, deconstruction and discourse analysis. It was this epistemological arsenal which he brought in the study of Islam and gave him the impetus to cast a critical eye on both the postulates of traditional Islamic studies and the field of orientalism. In doing this, his main focus was to assess the dialectic relationship between Islamic reason, which emerged and grew under the influence of orthodoxy (i.e., the closed official corpus), and the corresponding conditions in society, politics and culture leading, altogether, to what he ventured to call the 'dogmatic enclosure'.

As a part of the project he launched, Arkoun had to consider, in tandem, the transformation of the revelatory speech (revelation), which he often terms 'le fait coranique' (the Qur'anic event), into text, therefore, establishing 'le fait islamique' (the Islamic event). From this time onward, Arkoun suggests a 'system of belief and unbelief' began to operate freely without any competing actions (i.e., change) and has permitted with its discursive constraints and theological ideologies the protection and, if necessary, the mobilization of faith ever since. Until these days, what works under the system or stands inside this 'dogmatic enclosure', has been thinkable; i.e., belonging to what is presumptuously called faith, what does not or falls outside, is unthinkable.

In general, Arkoun's ideas seem to respond logically to his modern, largely Western education and training. Throughout them, he urged Arab, Muslim and western (i.e., non-Muslim) scholars, to be critical on Islamic tradition, which makes chaotic Islamic reasoning systems and interpretation. 'Islamology' made the best use of such a response. It was more than a methodology, rather the mode of the study itself whilst it struggled to offer a new way of thinking about Islam. In this sense, it departed, both conceptually and theoretically, from the field of classical Islamic studies including orientalism. I.e., he intended to explore how the studies confined to the dichotomy of Orientalism vs. Occidentalism have failed to liberate Islamic thought (studies) from both pro- and anti-Orientalism discourses.

As he did, he always urged to study it instead as an epistemological project arguing for a new 'ijtihad' (rethinking). One thinks of him initiating a methodology or a process of new thinking on Islam. In doing so, he brought into the study modern tools such as critical history, Derrida's deconstruction and comparative religion away from the fixed parameters of the two fields above, their intellectual impotence, stereotyped thinking or intransigent convictions.

In principle, Arkoun was critical of the conditions of Islamic thought, past and present, which -he concluded, explained (still do), the failing conditions of contemporary Arab and Islamic societies. He strongly reckoned that the spiritual and transformative

K C AL-KINDI CENTER R D FOR RESEARCH AND R D DEVELOPMENT Your gateway to world-class research

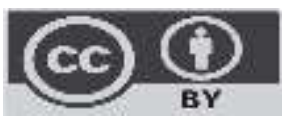

Published by Al-Kindi Center for Research and Development. Copyright (c) the author(s). This open access article is distributed under a Creative Commons Attribution (CC-BY) 4.0 license 
power of 'Revelation' shaping the early (formative) years of Islam (i.e., Medina prophetic experience) began to gradually lose its influences under the growing pressure orthodoxy. In many respects, the latter's obscuring character together with the struggles of authority it developed along the way has caused the true spirit of Islam to degrade and deteriorate into laws, doctrinal ways of life and, worst of all, ideologies of control. The corollary of this, Muslims, have suffered a prolonged state of decline and decay ever since, and in all aspects

For this reason, Arkoun launched his project the 'Critique of Islamic Reason' seeing in it what might help Islam retrieve its lost spiritual and humanistic essence and, in result, arise anew. In doing this, Arkoun had to make use of the many methods, instruments or tools modern social and humanistic sciences have already put in place. What Arkoun did was a good example, many assume, of how to manage the study with different methodologies; i.e., to take advantage of many combinations of western social sciences (e.g., historical method and deconstruction). His purpose was to view things through a modern wideangle lens. As such, he focused outward on sociocultural, political and theological aspects of Islam as far as he looked inward exposing a self-reflective and considerably thinking mode of study, which is, now, the eclectic methodology he ventured to describe as 'Applied Islamology'.

\section{Birth and Life}

Mohammed Arkoun was born on the $1^{\text {st }}$ of February, 1928 in Taourirt- Mimoun, Tizi Ouzou -a populated mountainous village in the great Algerian 'Kabylie' region wherein most people live from agricultural activities and handicraft trade. He grew up in a poor Amazigh family, which had left their original homeland Constantine sometime in late $19^{\text {th }}$ century for 'protection' (Arkoun, 2005, p 295) -as he stated in some of his correspondences. Born and raised under French colonial rule and in an ethnically Amazigh region, Arkoun was confronted at his early age by three languages and cultures, Kabylie, Arabic and French, which altogether shaped and influenced both his personal life and intellectual venture.

Kabylie, a sub-variety of Amazigh largely spoken in northern Algeria, performed its own role quite early in his life. This language, which as far as today appears in different, not mutually comprehensible forms, represents the culture of the Berber population situated in many regions across north Africa, from Libya to the far west of Maghreb. It made no difference in influence from Arabic, which itself comes in two main forms, totally different in their status, context and usage. As such, just as the Classical Arabic, the written and standardized form, which is commonly the language of religious and educational affairs, instituted his formal education, especially in Islamic thought, so too the Dialectic Arabic, the spoken and non-standardized form, instituted his informal one; i.e., it allowed him to live his life among the various 'lived' traditions of his own peoples. On its part, French, the language of administration (i.e., government venue), science, social prestige and French way of life, furthered his knowledge of the Western civilization, culture and thought, to which Arkoun's attraction was, gradually, growing.

Surely, this is what it was to be an Algerian in his and all times overall. Inasmuch as a few of the different indigenous peoples of Algeria have dwelt in mountainous areas, most of them have mingled with Arabs since the early years of Islam in the region and have experienced all sorts of cultural, social and linguistic interactions. This applies in some sense to all countries of the Maghreb. Anyway, all these traditions, values, social norms and cultural traits collectively were to the advantage of a knowledgeable figure like Arkoun. Each of them occupied a significant space in his life and academic journey. Now, the diversity, which his readers observe in his writings and thoughts, is the perfect reflection of the diversity he celebrated among his own people in his little village as well as in Algiers and Paris.

It all began very early in his native village where he completed his elementary schooling. When you live in a place like his own, it is always possible that you will have a variety of both expected and unexpected encounters. This was true about Arkoun, which, eventually, had the potency to evolve into regular aspects of his personal and professional character. "Comme Mouloud, je suis né et j'ai passé mon enfance et mon adolescence à Taourirt-Mimoun, l'un des sept villages qui forment le douar des Béni-Yenni en Kabylie. À ce titre, je puis évoquer quelques souvenirs de portée ethnographique, anthropologique et historique" (Arkoun, 2005 , p. 295). These words offer more than just a recount of his travel adventures; it adds to our knowledge of a man like him, to whom we, now, show much respect and admiration for his contributions to the entire scholarship on Islam. It also adds to our knowledge of his philosophy, which is, now, and above all, the perfect reflection, not just of those times but also of his own image as a devout scholar to cultural tolerance and pluralism (i.e., humanism).

Due to the many hardships of his family life and unendurable economic circumstances, it was difficult for him to continue his studies in the capital city of Algiers and was, somehow, obliged to complete his secondary education in a high school supervised by the 'White Fathers' -an elite of missionary teachers in the coastal state of Oran, Algeria. Upon his graduation in 1945, Arkoun enrolled at the University of Algiers from 1950 to 154, wherein he studied Arabic language and literature. In part due to the war of independence in Algeria and the growing tension between the Algerians and French authorities, Arkoun decided to seek his post-graduate studies in France marking a turning point in his own self-concept at a variety of levels. In this European country, 
Arkoun had a chance to explore much of Latin culture, literature and both Christian and Jewish theology, and he was fulsome in his interest and appreciation of all the disciplines in humanities and social sciences. In 1956, Arkoun graduated with an 'aggrégation' at the prestigious university of the Sorbonne. But it was till 1968 when he could establish himself academically with his dissertation on Ibn Miskawayh.

His teaching career was not quite different from his education in terms of richness, complexity and value. The scope and magnitude of such a career extended beyond all levels of Excellency and mastery. Had not it been magnificent, he should not have gained popularity internationally or modeled a classy and elegant intellectual. He was a professor at a number of prestigious institutions including the universities of Vincennes (Paris VIII), the Sorbonne, Lyon, London, California and New York. He was also the chairman of different academic departments of Arabic and Islamic studies and a member of many international centers and institutes most valuably his membership of the International Committee for the UNESCO Prize for the Origins of Peace Education in 2002 and the Scientific Council of the Swedish Institute in Alexandria, Egypt. Let alone the emeritus positions he held worldwide and the many honors and awards he received throughout his academic career. This includes the David Della Middle East Studies Prize from California in 2002, the Honorary Doctorate from the University of Exeter in 2008, Ibn Rushd Prize for Free Thought from Berlin, in 2003 and Doha: the Arab Capital City of Culture Prize in February 2010.

Overall, Arkoun was far from an ordinary thinker. Surely, he was a strong advocate of true scholarship, and, above all, a scholar who worked out his thoughts in defense and praise of free and independent thinking. "All my university teaching career, evidenced by consecutive generations of students, and all my writings bear the effects and the traces of a diligent and constant struggle to have and maintain intellectual independence" (Arkoun, 2009, p. 28) -he notes in one of his correspondences. By the virtue of his own courage, he withstood all forms of opposition, allegation and offense. While he did, the image of a thinker who wanted to freely express his own thoughts and perceptions about Islam was always recognized. In approaching this, Arkoun (2009) propounded what he ventured to define as 'applied Islamic studies' (i.e., Islamology), which was no more than "the uninterrupted devotion to historical and critical epistemology" (p. 29) -to use his terms.

Of utmost importance to us, his readers, is to know how his career seems, now, to entail strength, passion, sweat and a disciplined life lived for academic perfection. The facts shown are just examples of the many ways we can praise him. However, like almost all Arab and Muslim modernists, appreciation sometimes comes rarely and defamation comes often. Many critics have argued that his intellectual project; mainly in reference to his critique of Islamic reason and tradition, is merely a reflection of French thought and its critical stances on the Christian-Latin heritage, let alone an attempt to discredit the sanctity of Islam. This is something he complained bitterly about. Worse still, maybe, was the despair and frustration he felt at the European's view of him as a traditional, if not a traditionalist Muslim himself.

\section{An Intellectual in Revolt}

Arkoun had gone through a number of conflicts, much struggle and emotional pain sometimes before he finally began to establish his own project (Islamology) in the field of Islamic studies whilst many of his observers and critics continue to see in his dissertation on Ibn Miskawayh its starting point. His writings, lectures, teaching career and the chairs he held depict much of an intellectual character in revolt. His revolutionary approach to Islam -as a religion, cultural system and a historical experience, coupled with his unique reading of the Qur'an do, in fact, reflect his own critical disposition or temperament. The way he challenged orthodoxy, his personal perception or, rather introspection, offers a portrait of an 'intellectual in revolt' or a 'reflective researcher' -two terms Arkoun often defined himself with and are repeatedly quoted in many of his contemporaries' works. But it was not only the purely academic endeavors which made Arkoun a true, brilliant and influential 'chercheur penseur' now. His personal life and impressions provided the impulse, in different contexts, to move forward professionally and to give his ideas and perspectives more maturity and insight.

An academic experience like his can only bring about controversy. It was, and still is, seen as a venture of its own. Too much doubt, sometimes too impolite, was brought to his thoughts, not just from his Arab and Muslim contemporaries, but also from some scholars in the West. Had not this been too bothering Arkoun would not have complained about it. At different instances, he had to question the rationale behind the appellation (i.e., label) 'Muslim' often given to any scholar of his own religion and culture irrespective of how enlightening their studies are. While it may be not tempting to call a Muslim scholar a Muslim for the simple reason, they are, the fact that this is usually not true in the case of any Christian or Jewish scholar who works on Christianity or Judaism, makes of the appellation ridiculous, let alone offensive. Even when Islam is in question, observers may easily remark how Westerner thinkers are referred to as 'Orientalists', occasionally 'Arabists', while the term Muslim always hunts their Easterner colleagues.

Therefore, Arkoun had to focus his energies on the fight against two enemies: (Islamic) orthodoxy and (Western) hegemony. Inasmuch as he fought for pluralism, rationalism and humanism in Islamic thought, so too he had to rebel against a hegemonic 
Western scholarship which continues to construct an Eurocentric and hierarchical system of intellectuality among some western scholars. If this was the worst trouble Arkoun could see, there should be no way we ignore it as many Arab and Muslim thinkers are often held to inferior intellectual positions; this always happens regardless of how knowledgeable or insightful one can be. Arkoun never liked these kinds of views, where both the front of someone's work and the background look inadequate, insufficient for any academic purpose or showing no perceptive on no real pretext except they happen to be Arabs or Muslims. This fashionable notion, on the part of some, that Arabs and Muslims fail academic excellence overall is still one of the buzz fallacies in the West, which Arkoun himself had to confront throughout his entire life.

This is something we can stretch further in another direction as we still can sense these poetics and politics of exclusion in most Western narratives on Islam itself. Surely, we may expect that the public in the West be doubtful about the ideology of Islam. There is, in fact, a plenty of reasons to accept this; the popularity of anti-Islam dogmatic propaganda and the excess of media bias can only help such an attitude towards Islam raise and develop. Worse still, and truly 'painful' as Arkoun felt, is how many scholars do express the same views. The way they treat Islam manifests, in his opinion and, surely, in so many others', a clear-cut expression of ethnocentric and cultural chauvinism on their part. "A scholar or thinker's job was to confront the ready-made assumptions or repeated clichés and deconstruct them, and, surely not adopt or embed any of them" (2009, p. 29) -he averred.

No scholar, any scholar indeed, should claim something true or false about Islam unless they are avouched by the full evidence. This is not always true about many orientalists and Arabists unfortunately since; i.e., they, too often, have to make a priori assumptions, not only about Islam but Muslims and Arabs likewise, less or more noticeably. As they do, their exclusionary character unfolds, so too do their blatant fallacies only to demonstrate to what extent parts of Western scholarship on Islam suffer intellectual ambivalence and duplicity. It becomes even disgusting sometimes that they appear in "serious inconsistency with the true spirit of science and intellectuality" (Arkoun, 2009, P. 20).

Arkoun's fight against the two forces was too heavy to bear sometimes. It was less of an intellectual burden, more of a dilemma he had to suffer over long years. We may see it now as a double-trap situation. It worked in a two-way manner. Arkoun was (still is) trapped into religious affiliation; he was constantly presented with a seemingly endless stream of appellations like a 'Muslim' from many American and European scholars among whom some were his colleagues. This was something he met with strong emotional objection. Then, there were the many accusations of estrangement and betrayal of his own identity, culture or religion thereof, whose people brought against him. Some were too radical as heresy or atheism for his thoughts appeared, for some, to be at odds with the accepted doctrines of Islamic religion. This can be illustrated by the many aggressive reactions to his philosophy and perception, which all have happened to differ little in their impressive and emotional mode. If there was a conclusion to arrive at, which can express dislike and rejection to his thought, it should ascribe to his own vehement words that "his discourse stands in contrast to Islam" (2009, p. 22). Be it a struggle of its own, and a fight for his escape from such a trap, still in determinedly personal and intellectual terms, the description 'an intellectual in revolt' should not just make sense, but explains, perhaps, what Arkoun stands for in the modern scholarship on Islam.

\section{A Reflective Researcher}

Arkoun's personal and professional characters can be read in tandem for each represent or lead to the other. His upbringing in Algeria and travels are, in fact, the vehicles of his own academic endeavors, and at the same their perfect expressions. He exerted himself to make his own life a reference to his own intellectual strife; as he did, the personal journey became the academic one. His self-concept of an 'intellectual in revolt' is highly relevant to his own life -particularly his childhood and youth in Algeria. Arkoun was born and raised in a frustrating climate. The daily struggle of Algerians against the French authorities, the emotional effect of colonialism and the derogatory perception held by French towards the indigenous people, all, each in its way, influenced his perspective about himself, his people, culture and faith. At a certain level, it seems persuasive that his texts show a sort of vehement objection to the whole situation.

In this context, Arkoun's philosophy seems to significantly allude to the works of the French Algerian-born Nobel Prize in Literature winner Albert Camus; mainly to his 1951 book - or the long philosophical essay, 'The Rebel: An Essay on Man in Revolt'. Was Arkoun a rebel then? To some extent, yes. He happened to show an open resistance to the absurdity of some religious interpretations, claims to truth and traditions (orthodoxy) on one hand and, on the other hand, to the manipulations of cultural and ethnocentric reading of Islam. So what is a rebel? Again, in Camus's terminology, a rebel is "Un homme qui dit non. Mais s'il refuse, il ne renonce pas" (Camus, 1951, p. 25). I.e., 'a man who says no, but whose refusal does not imply a renunciation'. There are allusions to this, here; his rethinking Islam in the contemporary world, being critical on both Islamic reason and tradition together with his opposition to orientalism are, altogether, clear gestures of philosophical rebellion. It might stand for an Arkoun's 'no'; not only to the dogmatic explanations of Islam but also a no to an endless chain of false thoughts and misrepresentations of Islam in the West. After all, Arkoun's rebellion was, in large, against the already established doctrines of thought both classical studies of Islam and orientalism represent and a departure from their confines. 
If we accept the principle that any questioning of authority can only be treated or seen as rebellion, we shall immediately think of Arkoun as a rebellious thinker. From quite early, he tended himself to questions; every idea he suggested, a principle he established or a fact he unearthed, rose in rebellion. Arkoun was able to channel much of his criticism into such an act. When this was a choice made against what the two have come to shape, each in its own conditions and for its own purposes, there should be no other context to put his own acts except within this (rebellion). There were indeed different factors, both personal and intellectual, for him to go the direction he went, but, after all, they can only be seen, now, as forces of resistance. Again, Arkoun questioned both narratives, Islamic orthodoxy and orientalism alike. He did so to see how each differs from the other, little or much, surely in terms of the impact, not always function, and, at a broader sense, their influences over the image of Islam per se. Arkoun's questions might not be seen always as expressions of fierce rebellion, perhaps, but seriously disturbing nonetheless.

Anyway, it is beyond the scope of this section to elaborate on the influence of Albert Camus over Arkoun in detail. However, it is clear enough that both intellectuals developed a revolutionary attitude towards their own traditions; this should imply forms of knowledge, self-expressions, systems of behavior and values being all parts of their own cultures, and the patterns and doctrines of thought wherein all these elements rise and develop eventually. To this end, they, each in his own way, rejected all sorts of epistemological boundaries and stretched their thoughts, instead, into highly critical issues for maximum knowledge. In this sense, the venture of Islam, both as a theory and a historical process, in the eyes and mind of Arkoun becomes that of Camus' world.

After all, Arkoun can only be seen, now, as a combatant intellectual character; someone who was fully engaged in rethinking Islam. He was truly so, at least from the perspective of deconstructionists like him. He was a thinker who worked out his own system of thought in light of modern scholarship, not only on Islam but on the entire human phenomenon. Just as his personal life and travels added to his knowledge, so too did his interest in and juxtaposition of different disciplines in the realm of humanities and social sciences, e.g., theology, philosophy, anthropology, epistemology, history, discourse analysis, criticism and comparative religion. All these influences were only to help establish a quite moderate, comprehensive and objective narrative about Islam, which, in consequence, and as he puts it, should envision a truly humanistic, rational and enlightening Islam.

At certain times, Arkoun's scholarship can be read as a subversive work. Many observers still bring doubt, so often impolitely, into his ideas and perspectives. Nonetheless, today, his post-modern philosophy, rationality, passion for reform and devotion to an inclusively humanist, contemporary vision of Islam, if not all religions, have gained wide popularity in academia. He remains, perhaps to all, the epitome of a perfect Arab and Muslim humanist and modernist. His writings still keep much of their immense and impressiveness in the eyes and minds of many. His modern approach to Islamic thought, to which he contributed significantly, and his strife for what he calls "a plurality of meaning in Islam" or "the re-elaboration of the concept Islam" (Arkoun, 2009, p. 248) can never go invisible. They are clear enough not only to distinguish him from his Arab and Muslim contemporaries, but also to mark, in their own, a breakthrough with old traditions of thought. He did not just oppose history-old dogmatic demarcations and ideologies, rather he did so to revive Islam in the most perfect image it can reflect.

This says something, I assume, about his own attraction to the idea of an Islamic Renaissance (i.e., Islamic Enlightenment), which -as he always affirmed, the classical era of Islam had already witnessed. It also says about his struggle for modernity, not the one lived 'from above', rather what inspires, furthers and advances the real integration of Arab and Muslim societies into the modern culture of today's world. Perhaps, the expression of a true modernist and humanist may say it all about him. He can only deserve this, I guess, since his ideas did demonstrate, in fact, the rise of a true, serious and knowledgeable 'reflective researcher', the one who explored the Enlightenment ideals and tried to adapt them to Islam; maybe not necessarily the ideal type but fully the one among the few.

\section{Publications of Arkoun: A Library of its Own}

Arkoun wrote most of his works in French. There should be few, if no real indications to what might explain such an act. We may speculate that he did so for French is the language of Jean-Jacques Rousseau, Paul-Michel Foucault and Albert Camus whom he definitely embraced most among few other French thinkers. More convincing, perhaps, is the fact that French expresses itself, somehow, in the fusion of the crucible Western thought in its entirety. There could be other motives, with less or more significance, behind it. If I left this to my own speculations, I would say, Arkoun wrote more in French as an act of gratitude to the language and, hence, the culture of the country he spent most of his life in. Still, and most important of all, it sounds so normal if we consider his remarkable mastery of the language itself, which is, by all means, one of the qualities few might dare question or bring into doubt.

These works (in French) have grown to a fully established project destined mainly to the interpretation and extrapolation of Islam for the purpose of religious reformation principally. They all, each in its own way, represent a philosophical stance that affirms some notion of the value of people, individually and collectively, their freedom and progress. With this in mind, they hold the 
possibility that rethinking Islam in light of these two movements may lead to the realization of a different Islam; i.e., his own humanistic, liberal and dynamic type of religion. There is, surely, more to this than we think. After all, Arkoun wanted to see Arabs and Muslims progress in the contemporary world, with more passion and away from the attractions of their past.

The ideas, these books entail, seem to flow and circulate through a unique genre of writing and comprehensive lexical repertoire. Coherent, cohesive, stimulating, challenging if not provocative sometimes, they were and certainly remain to the advantage of Islamic contemporary thought. They all raise to the ideal type or the sorely needed perspective on Islam, either as a religion (i.e., a form of faith) or when it expresses itself as a social, political or cultural phenomenon. They do so, likewise, when Islam becomes a civilization in the very modern sense of term. We presume that these texts, most notably 'Contribution à l'Étude de l'Humanisme Arabe' (1970), 'Essais sur la Pensée Islamique' (1973) and 'Pour une critique de la raison Islamique' (1984) treat all these manifestations of Islam in a quite comprehensive manner, and, surely, in a modern mode. They all have come to differ in their forms, contents and proposals from earlier works on the subject and those of his contemporaries as they have done in their significance. One thinks of the successive generations of students and scholars alike, west and east, who continue to embrace them for they are all signs not only of real knowledge and intellectual tact, but of intellectual maturity and openness.

Arkoun's publications in Arabic are similarly important; they show qualities worthy of all respect and admiration as those in French do. Surely, many of them are more popular in the Arab world evoking no barriers of language. Yet, their expressive and impressive language, even in translation, goes some way to helping their popularity across the globe. What observers, any observer indeed, may point to, as being noticeable about them, is their variety, referential power and the same high level of focus on the problem of interpretation in Islam; they, all, grew out of the same intellectual solicitude of Arkoun's. This means, they -as his writings in French, are so critical on Islamic thought in general and the present conditions of Arab and Muslim societies. As such, they do not only provide a thorough diagnosis of the rise, development and historical impact of this thought, but also suggest "a way out of the terrible predicament the Arab-Muslim world live in" (Arkoun, 2009, p. 5) -as Hashem Saleh puts it.

In fact, all Arkoun's writings throughout four decades of scholarly work "fall broadly within the criticism of Islamic Reason. They represent the venture and the sum of Islamic thought in the modern age" (Arkoun, 2009, p. 6). This does not mean, by any sense, they negate Islam as many might falsely assume, but the confines of tradition, which have long obscured, marginalized or abandoned the true spirit of revelation. In any case, good critics usually benefit from much background research and work only for making informed judgment about their subject-matters; i.e., to know whether a certain fact, explanation/; or opinion is relevant, founded and covered sufficiently or not. They depend also on their good knowledge and the potency to detect a poor or a good argument about them in the process. I accept, at this certain point, this is true of Arkoun. As I do, it helps me affirm that Arkoun's criticism does not always mean making negative comments on Islam; rather it occasionally identifies some of its positive ones. More so, we have to bear in mind, again, that any time Arkoun assumes something wrong about Islam, he often does so, not to defame it, but to fix it. Criticism, above all, means also detecting what works well in any given context; this is how it traditionally identifies itself in the academic world anyway.

Once again, some (thinkers) may feel reluctant to criticize their own religion or even accept those who do; one of the barriers to criticism is how people generally feel sometimes in such situations. Nonetheless, Arkoun never felt this way. On the contrary, he always felt content to criticize, in part due to his prior knowledge of its significance, let alone his familiarity with works like Kant's. There always exists his own belief that such a modern method has the ability to unearth the real essence (i.e., the spiritual ethos) of Islam and the problems developed with its tradition. This says something, I would suggest, to its transformative power or overall effect towards the making of a new Islam or retrieving its lost nature. For this distinct purpose, Arkoun let it function as a process of assessment (i.e., rethinking) or "a general and complete inspection of all the elements of Islam" (2009, p. 6) -in Hashem's phrase. As he did, it was their "internal structures and historical development, especially in the first six centuries" $(2009$, p. 6) which hunted him along the way. Let be sure, this implied exposing and eliminating all forms of orthodoxy inherent in Islamic tradition whilst the process turned its hand, in parallel, to preserving its virtues or "the moral and spiritual essence of the message of the Great Islam" (Arkoun, 2009, p. 6).

Anyway, Arkoun's books in Arabic, most of which were translated into this language by Hashem Saleh, appear in different titles and subtitles. Each of them revolves, somehow, on the idea that "our knowledge of Islamic heritage, I mean of its formative era, is till theological and mythical" (Arkoun, 2009, p. 6), therefore, it serves no benefit, neither to Arabs and Muslims' understanding of their religion nor their 'being-in the-world'. These Books, like 'al-fikr al-'arabi' (Arab Thought), 'tarikhiyat al-fikr al-'arabi alislami' (The Historicity of Arab and Islamic Thought) and 'al-islam: al-akhlaq wa-siyasah' (Islam: Ethics and Politics), among others, set up -as the rest of his works does - his own system of thinking Islam. Indeed, they emerged to form an avant-garde model of Islamic discourse whist they, as far as today, allow a new possibility of both reading and re-reading towards the revival 
of the true Islam, not only as a religion, but also as a community, a culture and a reflection of its spiritual and humanistic aspirations.

There remain few writings in English. Eventually, Arkoun published five books in it; namely, 'Arab Thought', 'Rethinking Islam: Common Questions, Uncommon Answers Today', 'The Concept of Revelation: From the People of the Book to the Societies of the Book', 'The Unthought-of in Contemporary Islamic Thought' and finally 'Islam: to Reform or to Subvert'. Less or more frequently stated, these publications addressed themselves towards the same subject-matters and preoccupations (e.g., orthodoxy, orientalism, exegesis, jurisprudence, rationality, and the dichotomy of tradition vs. modernity). We can bring any of his concerns in them to the foreground and notice how he elaborated on each of them just to help his readers rethink Islam in all the aspects mentioned above. Part of it is how he engaged in understanding the religious text -the Holy Quran in particular. Just as he wanted such an understanding be through the literary composition and the evidence the text contains, so too he emphasized the significance of other elements.

Surely, one of the things he grounded in the process was the consideration of the many social, historical, cultural, ethical, ethnic and political contexts wherein each passage, message, expression or description of the text emerged and developed. This is to say, these books, separately or collectively, do reflect his own occupation as to trace the rise and development of Islamic tradition in general. In the meanwhile, they always answer the type of questions few Arabs and Muslims rise as who or what is to blame on the negative things like the excess of L'impensable (i.e., the unthought-of) in Islam, human rights or the ideology of violence. .

Now, I can only admit that all Arkoun's writings are of academic value. They come rich in their philosophical expressions and aspirations. They appear sometimes to have a literary character or impress, but they, above all, reflect a good knowledge of philosophy as manifested in its different schools and subjects. Perhaps, someone like me, who chose to make of Arkoun's works the basis of his own, might say that these books, altogether, seem to develop a powerful sub-discipline of philosophy within Islamic thought (i.e., Applied Islamology), if they do not stand for an independent school of its own.

\section{A Special Reference to Hashem Saleh}

Most of Arkoun's writings were in French; this always poses a big challenge to many Arab observers and readers whose French may not be good enough to deal with them in a proper manner. However, this is not always the case as long as there is a translator who helps us, we the Arabs, go beyond the barrier of language; someone, we are told, who happened to keep a close contact with Arkoun and whose language, even in translation, works as a bridge to much of Arkoun's thoughts. This man is the Syrian intellectual Hashem Saleh.

Born in Damascus, Syria in 1950, Saleh is, now, known by his own works on the Enlightenment, Islamic theology and the predicament of Arab and Muslim World. This aside, people also know Saleh from his numerous translations of almost all Arkoun's books in French. Before I elaborate on this, I should say Saleh is -as Arkoun was -a modernist himself who sees in the European struggle against the medieval practices of the church the major factor that sparked up the Enlightenment. As he does, he hopes for a similar experience in the Arab and Muslim world. He started from the same idea of Arkoun that the biggest problem of/in Islam is a 'theological problem' as manifested in orthodoxy only to suggest, therefore, that Arabs and Muslims must -and it is a 'big must' however, abandon this ideology before their religion can rise anew.

Inasmuch as we forge a link between Arkoun and Saleh on the basis of their similar standpoints, concerns and aspirations, Saleh translations tend to be independent somehow; i.e., to be his own works. Such an assumption has its logic, I assume given how Arkoun's ideas are nothing more than Saleh's in a way or another. Once again, we can always see this from the vantage point of how the similarity between their philosophical and conceptual backgrounds helps handle the process of translation, let alone it adds to it in many aspects. After all, had not Saleh engaged in this (translation), Mohammed Arkoun would have been less known to, now his non-French-speaking readers in the Arab world.

In approaching this field, Saleh had to keep a close contact with Arkoun; they used to meet frequently to manage their work together, weigh their arguments or remarks before Saleh could proceed in his translations. This was true, almost about all Arkoun's books. So, it was not about the type of details or mechanisms people usually bring to the foreground in translation like the binaries of source language vs. target language, writer vs. translator or form vs. content. Rather, it was more of a relationship between two intellectual figures who shared the same principles and had to express them in two different ways (i.e., languages). I would say, it was more of an intellectual intimacy bringing two figures together in their mode; Arkoun writes in French, Saleh does not just translate the writings into Arabic, he reflects on them as well, and he often does it in Arkoun's way.

Now, Saleh is the one who introduced Arkoun to the Arab world more than Arkoun himself did. He still does since his translations continue to make him the most reliable source of Arkoun's scholarship overall. What appeals most about Saleh's 
referential character is the fact he was one of his brilliant students in the 1970s at the excellent Paris-Sorbonne University. This is, perhaps, where exactly Saleh's importance lies; just as he knows how Arkoun thought and worked, so too he always prefigures what the subject of Islam might evoke. In other words, Saleh knows perfectly whence Arkoun's ideas came or generated, but he so equally realizes their complications of implications. One thinks of Saleh being familiar and aware of all Arkoun's observances, methodologies and motives. This, again, added to his knowledge, and, in turns, to the subject of the study per se.

Surely, there is more to this than intellectual juxtaposition. Whether a subject, any subject or issue in the realm of Islam, is treated separately, e.g., in its particular term, condition, time or space and from the perspective of a certain field of study only or combined, it is always too difficult to deal with. This is, eventually, true about all human and social phenomena anyway. This means, the type of Arkoun's works on Islam depends in their analysis on one's potency to observe things in sharp focus, be assertive in mode and persuasive being only ancillary factors as far as it does on one's critical thinking skills (e.g., precision, organization and emotional management). Here arises the question whether Saleh meets this or not.

If I see him from the vantage point of his intellectual baggage, language and philosophic aspirations, I would say he does. Besides as a mirror of Arkoun's thoughts and struggles, his translations were formulated, conceptualized and spoken in his own words; i.e., they mirror his own perspectives irrespective of how identical the two (Arkoun and Saleh) are. They appear rich in meanings and concepts. Their forms, likewise, depict the image of a true writer, of someone, I suppose, who professes his words and thoughts together with less faults or malfunctions. To this point, I can only affirm again that Saleh was (still is) aware of who Arkoun was. This, perhaps, led to him being not just the only one who translated his writings from French into Arabic, but also the perfect translator Arkoun could have imagined. How they fit into each other's perspective is always interesting. This says something, I confess, about me finding Arkoun in all Saleh's words and expressions.

\section{Conclusion}

Arkoun's writings (i.e., thoughts) are very valuable. Their significant contributions to modern scholarship on Islam cannot be easily doubted, nor can their influence. The way they handle the subject of Islam provides a sorely needed perspective on many of its topical issues (tradition, polity, religious fanaticism, etc.). They can only be read at this level if we consider their modern mode and the many details and highlights they provided. Above all, they, as much as his philosophy does, have come to be recognized for their fusion nature as they incorporate elements of different disciplines.

It is this referential aspect that makes of his writings something really valuable that is often unusual not to find a book, two or more of his in any library across the Arab-Muslim world and the West alike. Nonetheless, this is only one of the things that makes them so. Arkoun did not just write in Arabic, the standard native language of his, he also wrote in French, the language he professed, and English. While he did, his words came packed with marvelously clear and insightful expressions and ideas. It adds to their significance that he seems to give each of them an overview of where his thoughts were going or should go. Once again, these writings cover a wide range of concepts, ideas and perspectives; the only way to think of them is in their own terms -they represent the referential type of scholarly work on Islam, the religion he emotionally belonged to and chose to rethink it. At a certain level, each of these writings establishes a philosophy of its own; one that overtly displays what makes of a study a perfect one, especially when the subject matter is of real complications as this one on Islam.

At any case, many appreciate him for his courage, decent knowledge and the very character of a true philanthropist, which these writings perfectly picture. Once again, his mastership of historical critical thinking, his proclivity for comparative study of religion and for modern social and humanistic sciences -e.g., epistemology and anthropology, allow, altogether, a distinctive approach to the subject of Islam in general. His one of its kind sharp-eyed vision, perceptive knowledge and devotion to modernism make him a true modernist and of his mission a noble message. This says something, I assume, about him striving to liberate the strands of Islamic thought from centuries-old epistemological frameworks (i.e. the very medieval theological narrow-minded doctrinal views), and hence, Muslims and their societies as well.

\section{References}

[1] Arkoun, M. (2005). Appendix Avec Mouloud Mammeri à Taourirt-Mimoun: De la culture orale à la culture savante [With Mouloud Mammeri in Taourirt-Mimoun: From oral culture to knowledge culture] of Humanisme et Islam: Combat et propositions [Humanism and Islam: Combats and propositions]. Paris: Libraire Philosophique J.VRIN.

[2] Arkoun, M. (2009). Qadaya fi naqd al-'aql al-dini: Kayfa nafham al-islam al-yawm? [Issues on the critique of the religious reason: How to understand Islam today?]. Beirut: Dar Al Taliaa for Publishing \& Printing.

[3] Arkoun, M. (2009). Nahw naqd al-'aql al-islami [Towards the Critique of Islamic Reason]: Dar Al Taliaa for Publishing \& Printing.

[4] Saleh, H. (2009). Foreword. In M. Arkoun, Nahw naqd al-'aql al-islami [Towards the Critique of Islamic Reason]. Dar Al Taliaa for Publishing \& Printing.

[5] Camus, A. (1951). Homme Révolté [Revolted man]. Paris: Les Éditions Gallimard. 